\title{
Hubungan Kausalitas Pertumbuhan Ekonomi Dengan Investasi di Kota Pontianak Kajian Model Granger
}

\author{
Jamaliah* $^{*}$ \\ Universitas Tanjungpura
}

\begin{abstract}
This study aims to examine and analyze the causality relationship between economic growth and investment, in this case private investment in the city of Pontianak. The data used is time series data for 15 years $(2000$ - 2015), to qualify the test, the data in interpolation into quarter so that the data into 60 observations. There are two variables used in this research, namely; private investment in both domestic and foreign investment and economic growth. To test the presence or absence of causality relationship between variables used Granger causality test. Granger test results show that there is no causality between the two directions of economic growth and investment in the city of Pontianak, but there is a unidirectional causality. Partially, investment is related to economic growth but there is no relationship between economic growth and investment.
\end{abstract}

Keywords : Economic Growth, Investment, Causality Relationship

\section{PENDAHULUAN}

Pembangunan merupakan suatu proses menuju perubahan yang diupayakan secara terus menerus untuk meningkatkan kesejahteraan masyarakat. Hasil pembangunan dapat diukur antara lain dengan pertumbuhan ekonomi. Pertumbuhan ekonomi dapat diartikan juga sebagai proses kenaikan pendapatan nasional di mana suatu perekonomian dapat dikatakan mengalami pertumbuhan jika kegiatan ekonomi lebih tinggi daripada yang dicapai pada masa sebelumnya. Pertumbuhan ekonomi diartikan sebagai perkembangan kegiatan dalam perekonomian yang menyebabkan barang dan jasa yang diproduksi dalam masyarakat bertambah dan kemakmuran masyarakat meningkat. Kemampuan yang meningkat ini disebabkan oleh pertambahan faktor-faktor produksi baik dalam jumlah dan kualitasnya.

Peningkatan Produk Domestik Regional Bruto (PDRB) di Kalimantan Barat (Kalbar) mempunyai dampak positif terhadap kemajuan perekonomian di daerah tersebut. Peningkatan PDRB yang disebabkan adanya peningkatan pada sektor - sektor

\footnotetext{
${ }^{*}$ Korespondensi: Jamaliah, Jurusan Ilmu Ekonomi dan Studi Pembangunan, Fakultas Ekonomi dan Bisnis, Universitas Tanjungpura, Jalan Prof. DR. H. Hadari Nawawi, Pontianak, 78124, Kalimantan Barat, Indonesia. Email: jamaliah.fekon@gmail.com
} 
ekonomi di daerah baik kabupaten kita, yang selanjutnya pertumbuhan ekonomi akan memberikan dampak langsung pada perolehan pendapatan pemerintah.

Di Kalbar pertumbuhan ekonomi pada lima tahun terakhir rata-rata tumbuh sebesar 5,56 persen peningkatan yang cenderung tinggi jika dilihat dari skala daerah. Kondisi pertumbuhan ekonomi Kabupaten/Kota di Kalbar cenderung berfluktuasi, dimana disetiap Kabupaten/Kota menunjukkan pertumbuhan ekonomi yang berbedabeda, rata-rata pertumbuhan ekonomi tertinggi terdapat di kota Pontianak.

Tabel 1.Pertumbuhan Ekonomi Dan Struktur EkonomiMenurut Sektor Kota Pontianak Tahun 2010-2014

\begin{tabular}{lcccccccccc}
\hline \multirow{2}{*}{$\begin{array}{l}\text { Lapangan } \\
\text { Usaha Utama }\end{array}$} & \multicolumn{3}{c}{ Pertumbuhan Ekonomi Berdasarkan } & \multicolumn{5}{c}{ Struktur Ekonomi (\%) } \\
\cline { 2 - 12 } & $\mathbf{2 0 1 0}$ & $\mathbf{2 0 1 1}$ & $\mathbf{2 0 1 2}$ & $\mathbf{2 0 1 3}$ & $\mathbf{2 0 1 4}$ & $\mathbf{2 0 1 0}$ & $\mathbf{2 0 1 1}$ & $\mathbf{2 0 1 2}$ & $\mathbf{2 0 1 3}$ & $\mathbf{2 0 1 4}$ \\
\hline Pertanian & 4,32 & 4,65 & 4,73 & 4.90 & 4.83 & 1,46 & 1,45 & 1,44 & 1.42 & 1.41 \\
Industri & 2,34 & 2,50 & 2,71 & 3.06 & 3.03 & 7,72 & 7,32 & 7,01 & 6.81 & 6.78 \\
Pengolahan & & & & & & & & & & \\
Listrik dan Air & 4,28 & 4,52 & 4,50 & 7.83 & 5.88 & 0,52 & 0,50 & 0,49 & 0.48 & 0.48 \\
Minum & & & & & & & & & & \\
Bangunan & 5,27 & 5,81 & 6,46 & 8.65 & 7.66 & 19,54 & 19,54 & 19,80 & 19.98 & 20.07 \\
Perdagangan, & 6,24 & 5,97 & 6,66 & 8.13 & 6.96 & 24,51 & 25,46 & 26,07 & 26.89 & 26.96 \\
Hotel, Restoran & & & & & & & & & & \\
Pengangkutan & 9,11 & 9,04 & 9,19 & 8.03 & 9.27 & 18,12 & 18,36 & 18,47 & 18.32 & 18.30 \\
dan Komunikasi & & & & & & & & & & \\
Keuangan, & 5,55 & 5,64 & 6,03 & 6.92 & 6.06 & 9,42 & 9,23 & 9,02 & 8.78 & 8.75 \\
Persewaan \& & & & & & & & & & & \\
Jasa Persh & & & & & & & & & & \\
Jasa - Jasa & 2,51 & 2,93 & 3,34 & 5.18 & 3.57 & 18,71 & 18,14 & 17,70 & 17.31 & 17.24 \\
PDRB & $\mathbf{5 , 2 6}$ & $\mathbf{5 , 8 8}$ & $\mathbf{6 , 0 7}$ & $\mathbf{6 . 9 2}$ & $\mathbf{6 . 5 2}$ & $\mathbf{1 0 0}$ & $\mathbf{1 0 0}$ & $\mathbf{1 0 0}$ & $\mathbf{1 0 0}$ & $\mathbf{1 0 0}$ \\
\hline Sumber : Badan Pusat Statistik, (2016) & & & & & & & &
\end{tabular}

Setiap sektor mengalami laju pertumbuhan yang berbeda, demikian pula dengan kemampuan setiap sektor dalam menyerap tenaga kerja, seperti yang terlihat pada Tabel 1 dan Gambar 1. Pertama, terdapat perbedaan laju peningkatan produktivitas kerja di masing-masing sektor. Kedua, secara berangsur-angsur terjadi perubahan sektoral, baik dalam penyerapan tenaga kerja maupun kontribusinya dalam pendapatan nasional (Simajuntak, 2001:75). 


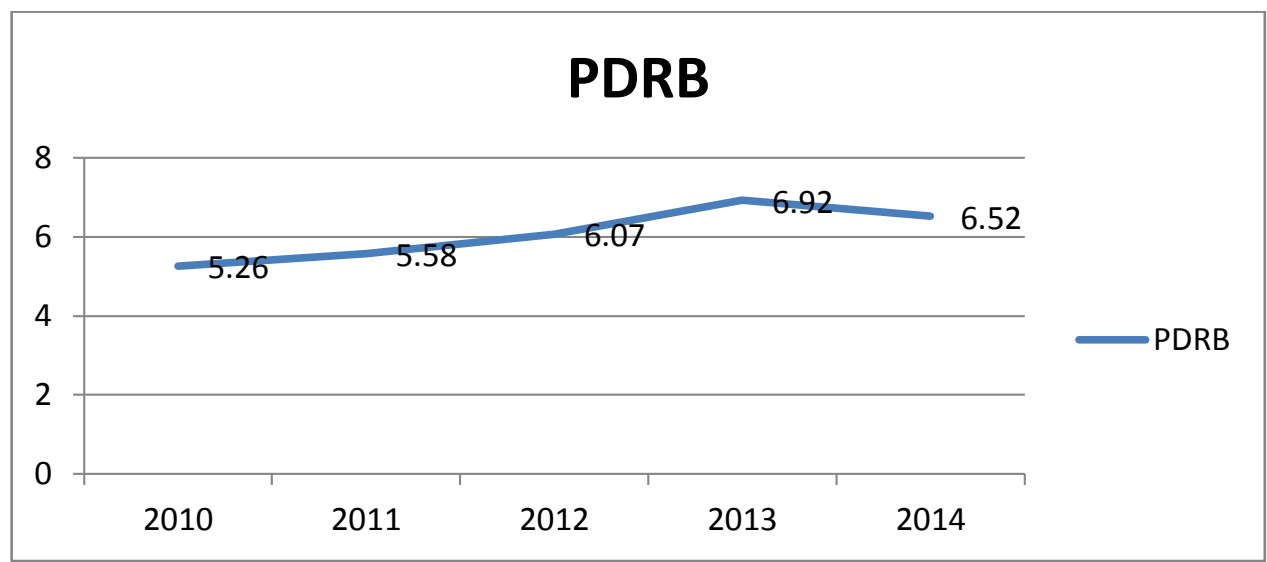

Sumber : Badan Pusat Statistik, (2016)

\section{Gambar 1. Pertumbuhan Ekonomi Kota Pontianak}

Meningkatnya pertumbuhan ekonomi mempunyai tendensi meningkatnya permintaan akan barang - barang dan jasa, yang berarti akan memerlukan produksi barang-barang dan jasa yang lebih banyak. Perubahan jumlah produksi ini berarti memerlukan penambahan faktor produksi yang sudah ada seperti modal dan tenaga kerja.

Tabel 2. Realisasi PMDN dan PMA Kota Pontianak Tahun 2009 - 2013 (juta Rupiah)

\begin{tabular}{ccc}
\hline Tahun & PMDN & PMA \\
\hline 2009 & 196.337 & 25.091 \\
2010 & 194.285 & 25.113 \\
2011 & 10.668 & 25.113 \\
2012 & 563.924 & 71.952 \\
2013 & 563.924 & 89.759 \\
\hline Rata - rata & $\mathbf{3 0 5 . 8 2 8}$ & $\mathbf{4 7 . 4 0 6}$ \\
\hline
\end{tabular}

Sumber : Badan Pusat Statistik, (2016)

Menurut Harrod-Domar (1984) dalam (Falianty, 2006), investasi sangat penting terhadap pertumbuhan ekonomi. Investasi akan meningkatkan stok barang modal yang memungkinkan mendorong output. Di Kota Pontianak realisasi investasi menunjukkan kecenderungan yang meningkat baik PMDN maupun PMA seperti yang terlihat pada Tabel 2. Hal itu dimungkinkan karena Kota Pontianak mempunyai sumber daya alam yang berpotensial untuk dikembangkan dengan tujuan menciptakan pertumbuhan ekonomi yang lebih tinggi, sehingga para investor mau menanamkan modal yang di kota Pontianak. Selain itu faktor - faktor lain juga memberikan daya tarik seperti kemudahan birokrasi, pelayanan dan sebagainya.

Penelitian ini terfokus pada hubungan kuasalitas antara pertumbuhan ekonomi dan investasi, mengingat investasi merupakan faktor pendukung terbesar terhadap pertumbuhan ekonomi dan sebaliknya, pertumbuhan ekonomi dapat mempengaruhi besarnya investasi. Beberapa studi telah memperkuat analisis tersebut, antara lain studi 
(Amalia, 2013) , melihat hubungan kausalitas investasi dengan pertumbuhan ekonomi di Indonesia. Dengan menggunakan model Vector Auto Regression (VAR) dan uji kausalitas Granger dan hasilnya menunjukkan bahwa investasi pemerintah dan investasi PMDN berpengaruh signifikan terhadap investasi PMA dan untuk terjadi sebaliknya. Studi (Setyowati, DL, \& Kuswati, 2008) menemukan kausalitas dua arah investasi asing terhadap pertumbuhan ekonomi di Indonesia. Hasil penelitian yang berbeda tersebut dimungkinkan adanya perbedaan dalam waktu penelitian, variabel, besarnya sampel, dan lain - lain. Pada studi tersebut memisahkan variabel investasi antara PMDN dan PMA tetapi dalam studi ini investasi swasta dilihat secara keseluruhan (gabungan PMDN dan PMA). Di Kota Pontianak, dilihat dari pergerakan data, pertumbuhan ekonomi yang tinggi tidak dibarengi dengan tingkat pertumbuhan investasi yang tinggi. Oleh karena itu, penulis terkait untuk menguji dan meneliti lebih lanjut yang difokuskan pada kausalitas antara pertumbuhan ekonomi dan investasi swasta baik PMDN maupun PMA.

Pemaparan yang telah dikemukakan di atas dijadikan dasar kajian dalam penelitian ini, sehingga rumusan masalah dalam penelitian ini adalah bagaimana hubungan kuasalitas antara pertumbuhan ekonomi dengan investasi di Kota Pontianak? Sehingga penelitian ini bertujuan untuk menganalisis hubungan kuasalitas antara pertumbuhan ekonomi dengan investasi di kota Pontianak.

\section{KERANGKA TEORI}

Pertumbuhan ekonomi berarti sebagai perkembangan kegiatan dalam perekonomian yang menyebabkan barang dan jasa yang diproduksi dalam masyarakat bertambah dan kemakmuran masyarakat menjadi meningkat. Jadi pertumbuhan ekonomi mengukur prestasi dari perkembangan suatu perekonomian. Kemampuan yang meningkat ini disebabkan oleh faktor-faktor produksi selalu mengalami pertambahan dalam jumlah dan kualitasnya. Investasi akan menambah barang modal dan teknologi yang digunakan juga berkembang.

Teori Keynes sangat mementingkan dari sisi permintaan agregat. Menurut Keynes, pendapatan total tergantung dari permintaan efektif yang terdiri dari permintaan konsumen serta permintaan investasi. Permintaan efektif inilah yang akan menentukan tingkat keseimbangan. Disaat terjadi ketidakseimbangan antara konsumsi dan pendapatan, menurut Keynes hal itu dapat dijembatani oleh investasi, dengan meningkatkan investasi maka akan mengakibatkan naiknya pendapatan, hal ini terjadi karena adanya efek multiplier (Wibisono, 2005).

Teori pertumbuhan neoklasik dikembangkan oleh Robert M. Solow (1970) dan T. W. Swan (1956) yang lebih dengan Model Solow - Swan menggunakan unsur pertumbuhan penduduk, akumulasi capital, kemajuan teknologi dan besarnya output yang saling berinteraksi ((Wahyuni, 2004: 73). Model pertumbuhan Solow menunjukkan bagaimana tabungan, pertumbuhan populasi dan kemajuan teknologi mempengaruhi tingkat output dan pertumbuhannya sepanjang waktu (Kuncoro , 1999) dalam (Wahyuni, 2004: 73). 
Hal senada dikemukakan oleh (Sukirno, 2010: 213), yang menyatakan bahwa faktor-faktor yang menentukan pertumbuhan ekonomi adalah tanah dan kekayaan alam lainnya, jumlah tenaga kerja, barang modal dan teknologi, sistem sosial dan sikap masyarakat.

Investasi adalah penanaman modal untuk satu atau lebih aktiva yang dimiliki dan biasanya berjangka waktu lama dengan harapan mendapatakan keuntungan di masa masa yang akan datang (Sunariyah, 2000: 4). Menurut (Dornbusch \& Fischer, 1994; Samuelson \& Nordhaus, 1996: 198) investasi meliputi penambahan stok modal atau barang di suatu negara, seperti bangunan, peralatan produksi, dan barang - barang investasi dalam waktu satu tahun. Investasi merupakan langkah untuk meningkatkan pertumbuhan ekonomi jangka panjang dan standar hidup masyarakat (Mankiw, 2007: $62)$.

Teori Neo Klasik menekankan pentingnya tabungan sebagai sumber investasi. Investasi dipandang sebagai salah satu penggerak utama pertumbuhan ekonomi dan pembangunan. Semakin cepat perkembangan investasi dibandingkan dengan laju pertumbuhan penduduk, maka akan semakin cepat perkembangan volume stok capital rata-rata per tenaga kerja. Makin tinggi rasio capital per tenaga kerja cenderung makin tinggi kapasitas produksi per tenaga kerja. Tokoh Neo Klasik, Sollow dan Swan memusatkan perhatiannya pada bagaimana pertumbuhan penduduk, akumulasi capital, kemajuan teknologi dan output saling berinteraksi dalam proses pertumbuhan ekonomi (Arsyad, 2010: 88-89).

Teori Harrod - Domar dalam (Sukirno, 2007: 256-257), mempertahankan pendapat dari para ahli ekonomi sebelumnya yang merupakan gabungan dari pendapatan dari pendapat kaum Klasik dan Keynes, dimana beliau menekankan peranan pertumbuhan modal dalam menciptakan pertumbuhan ekonomi. Teori Harrod - Domar memandang bahwa pembentukan modal dianggap sebagai pengeluaran yang akan menambah kemampuan suatu perekonomian untuk menghasilkan barang dan atau jasa, maupun sebagai pengeluaran yang akan menambah permintaan efektif seluruh masyarakat. Dimana apabila pada suatu masa tertentu dilakukan sejumlah pembentukan modal, maka pada masa berikutnya perekonomian tersebut mempunyai kemampuan untuk menghasilkan barang-barang dan atau jasa yang lebih besar (Boediono, 2006; Sukirno, 2007: 256-257).

Lebih lanjut menurut (Todaro, 2009) pertumbuhan ekonomi merupakan fungsi dari investasi, hal ini dikarenakan tingkat pertumbuhan ekonomi dan investasi merupakan hal yang tidak bisa dipisahkan dan saling membutuhkan.Semakin besar investasi maka semakin besar tingkat pertumbuhan yang bisa dicapai, sebaliknya semakin tinggi pertumbuhan ekonomi semakin besar pendapatan yang dapat ditabung dan diinvestasikan, ini merupakan fungsi dari pertumbuhan ekonomi. Meningkatnya pendapatan suatu daerah yang diukur dengan PDRB mempunyai tendensi meningkatnya permintaan akan barang-barang dan jasa konsumsi, yang berarti akan memerlukan produksi barang-barang dan jasa konsumsi yang lebih banyak. Ini berarti memerlukan 
penambahan modal yang sudah ada dengan menambah proyek investasi. Dengan demikian meningkatnya tingkat pendapatan akan mengakibatkan meningkatnya jumlah proyek investasi yang dilaksanakan oleh masyarakat/swasta (Todaro, 2009: 96) demikian juga untuk investasi asing langsung (Sarwedi, 2002).

Ould (2015) dalam penelitiannya dengan menggunakan teknik ekonometrik seperti Unit-Root Test, Granger-Causality Test dan Ordinary Least Square (OLS) menemukan Produk Domestik Bruto (PDB), Investasi Domestik Bruto (FDI) dan Pembentukan Modal Bruto (GFCF) di Mauritania memiliki hubungan positif dan signifikan. Sedangkan tes kausalitas granger menunjukkan tidak ada kausalitas antara PDB, FDI dan GFCG.

Penelitian Ayanwale (2007) yang menguji hubungan empiris antara FDI yang tidak ekstraktif dan pertumbuhan ekonomi di Nigeria dengan menggunakan teknik Ordinary Least Square (OLS), menunjukkan hasil bahwa FDI memiliki dampak positif terhadap pertumbuhan ekonomi.

Chih-Chiang, Jyun-Yi, \& Hsu, (2008) melihat apakah FDI mempromosikan pertumbuhan ekonomi dengan menggunakan analisis regresi ambang batas. Analisis empiris menunjukkan bahwa FDI sendiri memainkan peran samar dalam memberikan kontribusi terhadap pertumbuhan ekonomi berdasarkan sampel dari 62 negara yang mencakup periode 1975 sampai 2000 dan menemukan bahwa PDB awal dan sumber daya manusia merupakan faktor penting dalam menjelaskan FDI. FDI ditemukan memiliki dampak positif dan signifikan terhadap pertumbuhan ketika negara tuan rumah memiliki tingkat PDB awal dan modal manusia yang lebih baik.

Falki (2009) mengeksplorasi efek FDI terhadap Pertumbuhan Ekonomi Pakistan. Dia mengumpulkan data yang mencakup periode 1980 sampai 2006 dari Buku Pegangan Ekonomi Pakistan-2005 yang diterbitkan oleh Negara Bagian Pakistan dan Indikator Pembangunan Bank Dunia. Variabel modal dalam negeri, modal asing dan tenaga kerja digunakan dalam penelitian ini dengan bantuan teori pertumbuhan endogen dan menerapkan analisis regresi. Temuan tersebut mengungkapkan hubungan negatif yang negatif secara negatif antara PDB dan arus masuk FDI di Pakistan.

Amalia (2013) penelitian ini bertujuan untuk mengetahui bagaimana hubungan kausalitas antara investasi, dalam hal ini investasi pemerintah dan investasi sektor swasta dengan pertumbuhan Indonesia. Data yang digunakan adalah data time series selama 36 tahun dan merupakan data sekunder. Ada beberapa variabel yang digunakan dalam penelitian ini, yaitu: pertumbuhan proxy penasihat investasi charter dengan nilai PDB, investasi proxy pemerintah dengan pencairan pemerintah, investasi sektor swasta asing (PMA) dan investasi sektor swasta dalam negeri (PMDN). Metode yang digunakan analis untuk hubungan kausalitas adalah dengan pendekatan model Vector Auto Regression (VAR). Untuk menguji tidak ada hubungan kausal antara variabel yang diterapkan dengan uji kausalitas Granger. Hasil pengujian terhadap Granger menunjukkan bahwa ada tiga hubungan yang berbarengan. Berdasarkan hasil tersebut, 
maka disandingkan produk domestik bruto (PDB), investasi pemerintah dan investasi PMDN berpengaruh signifikan terhadap investasi PMA dan tidak terjadi sebaliknya.

Setyowati et al., (2008) ), investasi merupakan salah satu komponen penting bagi keberlanjutan proses pembangunan ekonomi. Tujuan penelitian yang ingin dicapai adalah untuk memperkirakan pengaruh investasi asing terhadap pertumbuhan ekonomi, dan sebaliknya. Manfaat yang bisa didapat adalah untuk meningkatkan eksistensi teori pertumbuhan ekonomi yang bisa diterapkan di Indonesia, memperkuat hasil penelitian sebelumnya, dan memperjelas pemahaman teori pertumbuhan ekonomi. Salah satu cara untuk menganalisis pengaruh jangka pendek dan jangka panjang adalah dengan menggunakan model dinamis. Dalam penelitian ini, model yang digunakan adalah Model Koreksi Kesalahan Engle Granger (EG-ECM), berdasarkan teorema representasi Granger. Dari hasil penelitian diketahui bahwa variabel yang memiliki dampak signifikan dalam jangka pendek adalah Foreign Direct Investment terhadap PDB dan sebaliknya. Hasil penelitian ini membuktikan adanya kausalitas dua arah.

\section{METODA PENELITIAN}

Bentuk penelitian yang digunakan dalam penelitin ini adalah penelitian asosiatif, yaitu penelitian yang mencari hubungan kausalitas (timbal balik) antara variabel pertumbuhan ekonomi dengan variabel investasi di Kota Pontianak. Dimana variabel pertumbuhan ekonomi merupakan variabel yang bisa menjadi variabel independen atau sebaliknya dan variabel investasi merupakan variabel yang bisa menjadi variabel dependen atau sebaliknya. Pertumbuhan ekonomi dalam penelitian ini diukur dengan perkembangan nilai riil PDRB Kota Pontianak. Sedangkan investasi adalah nilai realisasi dari investasi swasta baik PMDN dan PMA kota Pontianak. Investasi PMDN dalam satuan Rupiah sedangkan PMA dalam ribuan US \$ yang kemudian dikonversi dalam Rupiah.

Data yang digunakan dalam penelitian ini adalah data sekunder yang berbentuk data time series dari tahun 2000 - 2015 di kota Pontianak. Dalam penelitian ini data menggunakan lag selama satu tahun, dimana investasi dari tahun 2000 - 2014 sedangkan pertumbuhan ekonomi dari tahun 2001 - 2015. Untuk memenuhi kriteria penelitian data di interpolasi menjadi kuartal dengan rumus sebagai berikut ;

$\mathrm{Q} 1=1 / 4\{\mathrm{yt}-4.5 / 12(\mathrm{Yt}-\mathrm{Yt}-1)\}$

$\mathrm{Q} 2=1 / 4\{\mathrm{yt}-1.5 / 12(\mathrm{Yt}-\mathrm{Yt}-1)\}$

$\mathrm{Q} 3=1 / 4\{\mathrm{yt}-1.5 / 12(\mathrm{Yt}-\mathrm{Yt}-1)\}$

$\mathrm{Q} 4=1 / 4\{\mathrm{yt}-4.5 / 12(\mathrm{Yt}-\mathrm{Yt}-1)\}$

Dimana Q1, Q2, Q3, dan Q4 adalah data triwulan yang dicari, sedangkan Yt adalah data tahunan pada tahun tersebut dan Yt-1 adalah data tahunan pada tahun sebelumnya. Sehingga jumlah observasi menjadi 60 (15 x 4) observasi. Data yang digunakan bersumber dari Badan Pusat Statistik, (2016) Kalimantan Barat serta instansi lain yang mempunyai hubungan dengan penelitian ini. 
Metode analisis yang digunakan dalam penelitian ini adalah model kausalitas Granger, akan tetapi sebelum menguji hubungan dalam penelitian terlebih dahulu dilakukan pengujian stasioneritas data untuk menentukan data stasioner atau tidak pada tingkat level atau first different, dan selanjutnya dilakukan pengujian Lag Length Criteria untuk menentukan pada lag berupa data paling optimal dilihat dari SIC yang ditentukan dengan tanda bintang. Selanjutnya baru dilakukan pada uji Kausalitas Granger untuk melihat variabel mana yang mempunyai hubungan kausalitas atau tidak.

Uji granger yang dilihat adalah pengaruh masa lalu terhadap kondisi sekarang, sehingga data yang digunakan adalah data time series. Uji kausalitas adalah uji yang mengukur kegiatan hubungan antara dua variabel atau lebih, dan menunjukkan arah hubungan antara variabel bebas dan variabel terikat. Dengan kata lain, kausalitas mempertanyakan masalah sebab akibat dalam penelitian ini.

\section{HASIL PENELITIAN DAN PEMBAHASAN}

\subsection{Pengujian Stasioneritas}

Pengujian akar unit yang dilakukan melalui pada level kemudian dilanjutkan dengan melakukan uji akar unit pada tingkat first different. Hasil pengujian akar unit pada tingkat level Kota Pontianak secara umum tidak stasioner sehingga dilanjutkan kepada tingkat first different dimana pada tingkat first different atau pada derajat integrasi satu (1) baik variabel pertumbuhan ekonomi maupun variabel investasi dinyatakan stasioner, dimana hal tersebut dapat dilhat pada tabel berikut.

Tabel 3. Hasil Uji Stasioneritas Tingkat First Different Pertumbuan Ekonomi dengan Investasi Kota Pontianak

\begin{tabular}{|c|c|c|c|c|c|c|}
\hline \multirow[b]{2}{*}{ Variabel } & \multirow[b]{2}{*}{$\begin{array}{c}\text { ADF } \\
\text { Statistic }\end{array}$} & \multicolumn{3}{|c|}{ Nilai Kritis Mc Kinon } & \multirow[b]{2}{*}{ Keterangan } & \multirow[b]{2}{*}{ Prob } \\
\hline & & $\begin{array}{c}\text { Test } \\
\text { Critical } \\
\text { Value 1\% }\end{array}$ & $\begin{array}{c}\text { Test } \\
\text { Critical } \\
\text { Value 5\% }\end{array}$ & $\begin{array}{c}\text { Test } \\
\text { Critical } \\
\text { Value } 10 \%\end{array}$ & & \\
\hline Pertumbuhan & -6.4602 & -3.5482 & -2.9126 & -2.5940 & Stasioner & 0.000 \\
\hline \multicolumn{7}{|l|}{ Ekonomi } \\
\hline Investasi & -5.9680 & -3.5683 & -2.9211 & -2.5985 & Stasioner & 0.000 \\
\hline
\end{tabular}

Berdasarkan Tabel 3 variabel pertumbuhan ekonomi dan investasi di kota Pontianak pada uji stasioneritas pada tingkat first difference menunjukkan nilai probabilitas < dari $\alpha(5 \%)$ maka data dinyatakan stasioner. Karena data dinyatakan stasioner pada tingkat first difference dan variabel penelitian yang diuji maka pengujian selanjutnya dilanjutkan dengan uji Lag Length Criteria.

Hasil lag optimal dalam penelitian ini menggunakan metode Schwarz Information Criterion (SC). Pengujian kepanjangan lag dilakukan di kota Pontianak dimana lag optimal ditunjukkan dengan tanda (*). Berikut disajikan hasil uji Lag Length Criteria. 
Tabel 4. Hasil Uji Lag Length CriteriaKota Pontianak

\begin{tabular}{cc}
\hline Lag & 2 \\
\hline SIC & $0.8441^{*}$
\end{tabular}

Berdasarkan Tabel 4 diperoleh bahwa kota Pontianak memiliki panjang lag 2, ini berarti kota Pontianak mempunyai nilai paling optimal. Berdasarkan pada pertimbangan bahwa lag direkomendasikan oleh SC yang ditunjukkan dengan tanda bintang (*) yang menunjukkan lag optimal. Hasil ini menunjukkan bahwa kedua variabel yang diteliti memenuhi syarat untuk dilakukan uji granger.

Dalam uji kausalitas granger yang digunakan untuk melihat adakah hubungan kausalitas antara variabel - variabel yang diuji. Hipotesis untuk menentukan ada tidaknya hubungan diantara variabel - variabel yang diuji adalah jika nilai probabilitasnya $>$ dari $\alpha(5 \%)$ maka tidak ada hubungan serta jika nilai probabilitas $>$ dari $\alpha(5 \%)$ maka terdapat hubungan.

Tabel 5. Hasil Pengujian Kausalitas Granger Kota Pontianak

\begin{tabular}{ccc}
\hline Variabel & Nilai & Hubungan \\
\hline Pertumbuhan Ekonomi $\longrightarrow$ Investasi & 0.2922 & Tidak ada kausalitas \\
Investasi $\longrightarrow$ Pertumbuhan Ekonomi & 0.0086 & Ada kausalitas \\
\hline
\end{tabular}

Berdasarkan pada Tabel 5 tidak terdapat kausalitas antara variabel pertumbuhan ekonomi dan variabel investasi karena nilai probabilitas $0.2922>0.05$, sedangkan variabel investasi dan variabel pertumbuhan ekonomi terdapat kausalitas karena nilai probabilitas $0.0086<0.05$. Hal ini dapat disinyalikan bahwa tidak ada hubungan kausalitas dua arah antara pertumbuhan ekonomi dan investasi. Hubungan kausalitas terjadi satu arah antara investasi dengan pertumbuhan ekonomi.

Secara umum hubungan antara variabel yang diuji hanya mempunyai hubungan searah, hal tersebut disebabkan oleh beberapa faktor, diantaranya dapat dilihat dari sisi pertumbuhan ekonomi yang diambil dari perkembangan PDRB serta masuknya investasi baik PMA dan PMDN di kota Pontianak yang terealisasikan di berbagai sektor ekonomi.

Kota Pontianak yang sektor ekonominya berbeda dibandingkan dengan kabupaten/kota yang ada di Kalbar, secara umum sektor penyumbang terbesar terhadap peningkatan PDRB di kota Pontianak selama kurun waktu 2010-2015 adalah sektor perdagangan, industri pengolahan serta konstruksi. Pada tahun 2014 sektor perdagangan, merupakan paling dominan di kota Pontianak. Dengan kontribusi sebesar 18,42 persen terhadap pembentukan PDRB di kota Pontianak. Kategori kedua yang berperan dalam PDRB adalah industry pengolahan sebesar 17,08 persen diikuti oleh konstruksi 16,27 persen. Transportasi sebesar 8,95 persen, jasa keuangan sebesar 8,99 persen, administrasi pemerintah serta jasa pendidikan masing-masing 7 persen.

Hubungan yang searah di kota Pontianak ini sejalan dengan penelitian Umam (2016) yang menunjukkan bahwa kabupaten Bengkayang juga memiliki hubungan yang 
searah. Akan tetapi berbeda dengan kabupaten Kapuas Hulu yang mempunyai hubungan dua arah.

Apabila dilihat secara parsial hubungan yang searah yaitu hubungan antara investasi dengan pertumbuhan ekonomi dengan arah yang positif. Ini berarti bahwa apabila investasi naik maka pertumbuhan ekonomi juga cenderung naik atau meningkat. Hal ini dimungkinkan karena investasi di Kota Pontianak lebih difokuskan pada sektorsektor pengangkutan dan komunikasi, bangunan dan perdagangan, perhotelan dan restoran (daya serapan tenaga kerja minim). Ketiga sektor ini lebih banyak menyerap penyerapan modal fisik dan memberikan tingkat produktivitas yang besar sehingga output yang dihasilkan lebih besar pula, yang pada gilirannya secara langsung berdampak pada meningkatkan pertumbuhan ekonomi, seperti terlihat dalam data sebagai berikut :

Tabel 6. Pertumbuhan Ekonomi dan Daya Serap Tenaga Kerja di Kota Pontianak

\begin{tabular}{|c|c|c|c|c|c|}
\hline \multirow{2}{*}{$\begin{array}{c}\text { Lapangan Usaha } \\
\text { Utama }\end{array}$} & \multicolumn{2}{|c|}{$\begin{array}{c}\text { Jumlah Pekerja } \\
\text { (Jiwa) }\end{array}$} & \multirow{2}{*}{$\begin{array}{c}\text { Perubahan } \\
\text { Pekerja } \\
\text { (jiwa) }\end{array}$} & \multirow{2}{*}{$\begin{array}{c}\text { Pertumbuhan } \\
\text { Ekonomi } \\
(\%)\end{array}$} & \multirow{2}{*}{$\begin{array}{c}\text { Daya } \\
\text { Serap } \\
\text { (absolut) }\end{array}$} \\
\hline & 2013 & 2014 & & & \\
\hline Pertanian & 5,910 & 14,215 & 8.305 & 4.83 & 1.719 \\
\hline Industri Pengolahan & 19,638 & 20,815 & 1.195 & 3.03 & 394 \\
\hline Listrik dan Air Minum & 2,897 & 2,949 & 34 & 5.88 & 6 \\
\hline Bangunan & 39,020 & 29,724 & $(9.296)$ & 7.66 & $(1.214)$ \\
\hline Perdagangan, Hotel, & & & $(702)$ & 6.96 & (101) \\
\hline Restoran & 77,905 & 77,203 & & & \\
\hline Pengangkutan dan & & & & & \\
\hline Komunikasi & 21,833 & 16,755 & $(5.078)$ & 9.27 & $(548)$ \\
\hline Keuangan, Persewaan & & & & & \\
\hline \& Jasa Persh & 13,678 & 20,223 & 6.545 & 6.06 & 1.080 \\
\hline Jasa - Jasa & 61,101 & 62,353 & 1.252 & 3.57 & 351 \\
\hline Total & 241,982 & 244,236 & 2.254 & 6.52 & 346 \\
\hline
\end{tabular}

Hasil penelitian ini sesuai dengan teori ekonomi bahwa investasi sebagai penentu utama dan fungsi dari pertumbuhan ekonomi atau pertumbuhan ekonomi sangat ditentukan oleh investasi baik PMDN maupun PMA (Smith: 1776) dalam (Jhingan, 2000), Harrord Domar (1939) dalam (Sukirno, 2007), Keynes (1936) dalam (Wibisono, 2005), Solow Swan (1956) dalam (Wahyuni, 2004).

Sebaliknya apabila dilihat korelasi antara pertumbuhan ekonomi dan investasi ternyata menunjukkan hasil yang tidak ada hubungan berdasarkan uji granger karena nilai probabilitas sebesar 0,2922>0,05. Tidak adanya hubungan antara pertumbuhan ekonomi dan investasi dapat disebabkan oleh beberapa faktor. Pertama, dimungkinkan karena rendahnya kualitas pertumbuhan ekonomi antara lain tidak meratanya pertumbuhan ekonomi pada semua sektor. Kedua, dapat juga dimungkinkan karena belum tingginya kesadaran masyarakat untuk menggunakan pertumbuhan ekonomi atau pendapatannya untuk investasi, tapi lebih banyak digunakan untuk konsumsi, sehingga pertumbuhan ekonomi yang tinggi tidak secara langsung berkorelasi dengan 
meningkatnya investasi. Selain itu dapat pula disebabkan investasi yang terjadi di kota Pontianak terfokus pada investasi asing.

Hasil penelitian ini ternyata tidak sejalan dengan hasil penelitian (Setyowati \& Fatimah, 2007) dan Teori Todaro (2009) yang mengatakan bahwa pertumbuhan ekonomi merupakan fungsi dari investasi dan sebaliknya, jadi semakin tinggi pertumbuhan ekonomi maka semakin besar pendapatan yang dapat ditabung dan diinvestasikan. Hasil yang berbeda ini menunjukkan bahwa pada umumnya masyarakat kota Pontianak menerapkan demonstrative effeck, pola hidup konsumtif karena gengsi, selera dan lainlain. Meskipun demikian kondisi kota Pontianak ini relative sama dengan hasil penelitian (Umam, 2016) di kabupaten Mempawah, Bengkayang dan Sintang. Hasil studi ini juga sesuai dengan hasil penelitian (Amalia, 2013) tentang hubungan kausalitas antara investasi dan pertumbuhan ekonomi di Indonesia. Demikian juga dengan hasil penelitian (Astari, 2014; Sabono \& Kusreni, 2013).

\section{SIMPULAN}

Berdasarkan hasil pengujian model Granger, bahwa tidak terdapat hubungan kausalitas atau hubungan timbal balik antara pertumbuhan ekonomi dan investasi di kota Pontianak.

Terdapat hubungan searah, yang secara parsial terdapat hubungan antara investasi dan pertumbuhan ekonomi di kota Pontianak. Hubungan ini menunjukkan bahwa investasi yang ditanamkan memberikan dampak secara langsung terhadap pertumbuhan PDRB dan meningkatnya pertumbuhan ekonomi. Investasi lebih difokuskan pada sektor - sektor yang produktivitasnya tinggi seperti perdagangan, industry dan jasa - jasa. Selain itu juga terjadinya efisiensi dalam investasi (modal dan teknologi) yang dapat mempengaruhi proses produksi dan meningkatkan output.

Secara parsial menunjukkan tidak ada hubungan antara pertumbuhan ekonomi dan investasi di kota Pontianak. Hal ini menunjukkan bahwa rendahnya kualitas pertumbuhan ekonomi yang terjadi, yang dapat dilihat dari tidak meratanya output yang dihasilkan dan rendahnya tingkat kesadaran masyarakat untuk menabung dan berinvestasi, karena kecenderungan pendapatan yang diperoleh lebih difokuskan pada kegiatan konsumsi.

Pemerintah kota Pontianak hendaknya berusaha meningkatkan investasi baik PMDN maupun PMA karena adanya hubungan searah antara variabel investasi dan pertumbuhan ekonomi. Artinya investasi merupakan faktor utama yang perlu didorong dan mendapat perhatian sehingga perlu mengevaluasi atau menerbitkan produk - produk kebijakan ekonomi yang mampu menarik investasi lokal dan asing. 
Pemerintah kota Pontianak perlu memotivasi masyarakat dengan gerakan gemar menabung dan membiasakan masyarakat untuk berinvestasi, pola hidup yang produktif dan menyediakan banyak kesempatan untuk menjadi enterprenuer.

Melakukan penyuluhan dan menggalakkan promosi - promosi untuk hidup rasional dan mengurangi aktivitas non produktif, melalui pendidikan karakter di sekolah - sekolah formal maupun informal.

\section{DAFTAR PUSTAKA}

Amalia, F. (2013). Hubungan Kausalitas Investasi dengan Pertumbuhan Ekonomi Indonesia, 2(1), 1-16.

Arsyad, A. (2010). Media Pembelajaran. Jakarta: PT.Raja Grafindo Persada.

Astari, C. (2014). Analisis Kausalitas Granger antara PDRB, Investasi dan Belanja Modal di Provinsi Jawa Tengah. Economic Development Analysis Journal, 3(2).

Ayanwale, A. B. (2007). FDI and Economic Growth : Evidence From Nigeria.

Badan Pusat Statistik. (2016). Kalimantan Barat Dalam Angka 2005-2006. Pontianak.

Boediono. (2006). Teori Pertumbuhan Ekonomi : Seri Sinopsis Pengantar Ilmu Ekonomi No.4. Yogyakarta: BPFE UGM.

Chih-Chiang, Jyun-Yi, W., \& Hsu. (2008). Does Foreign Direct Investment Promote Economic Growth? Evidence from a Threshold Regression Analysis. Bulletin Economics.

Dornbusch, R., \& Fischer, S. (1994). Makro Ekonomi. Alih Bahasa Julius A. Mulyadi. Jakarta: Penerbit Erlangga.

Falianty, T. A. (2006). Foregn Direct Investment di Indonesia: Peranannya Terhadap Kinerja Makroekonomi, Masalah-masalah yang Dihadapi, dan Tantangan ke Depan. Bisnis \& Ekonomi Politik Quarterly Review of the Indonesia Economy, 7(2), 69-86.

Falki, N. (2009). Impact of Foreign Direct Investment on Economic Growth in Pakistan. International Review of Business Research Papers, 5(5), 110-120.

Jhingan, M. (2000). Ekonomi Pembangunan dan Perencanaan. Penerbit Rajawali Press. Mankiw, G. (2007). Teori Makroekonomi. Jakarta: Erlangga.

Ould, L. (2015). An Investigation of the Impact of Foreign Direct Investment on Economic Growth: A Case Study of Mauritania. International Journal of Economics \& Management Sciences, 4(2), 1-5. https://doi.org/10.4172/21626359.1000224 
Sabono, J. D., \& Kusreni, S. (2013). Analisis Hubungan Kausalitas antara Investasi dan PRDB Provinsi Maluku. Jurnal Ekonomi Dan Bisnis, 23(2), 122-134.

Samuelson, P. A., \& Nordhaus, W. D. (1996). Makro Ekonomi (Edisi ke 1). Jakarta: Erlangga.

Sarwedi. (2002). Investasi Asing Langsung di Indonesia dan Faktor Yang Mempengaruhi. Jurnal Akuntansi Dan Keuangan, 4(1), 17-35.

Setyowati, E., DL, W., \& Kuswati, R. (2008). Kausalitas Investasi Asing Terhadap Pertumbuhan Ekonomi: Error Correction Model. Jurnal Ekonomi Dan Studi Pembangunan, 9(1), 69-88.

Setyowati, E., \& Fatimah, S. (2007). Analisis Faktor-Faktor yang mempengaruhi Investasi Dalam Negeri di Jawa Tengah 1980-2002. Jurnal Ekonomi Pembangunan, $8(1), 62-84$.

Simajuntak, P. J. (2001). Pengantar Ekonomi Sumber Daya Manusia. Jakarta: Lembaga Penerbit Fakultas Ekonomi Universitas Indonesia.

Sukirno, S. (2007). Teori Ekonomi Pembangunan. Jakarta: Rajawali Press.

Sukirno, S. (2010). Makro Ekonomi. Teori Pengantar. Edisi Ketiga. Jakarta: PT. Raja Grasindo Persada.

Sunariyah. (2000). Pengantar Pengetahuan Pasar Modal. Edisi Kelima. Yogyakarta: YKPN - Yogyakarta.

Todaro, M. (2009). Pembangunan Ekonomi. Edisi Kelima. Jakarta: Bumi Aksara.

Umam, S. (2016). Hubungan Kausalitas Investasi dengan Pertumbuhan Ekonomi Kabupaten/Kota di Kalimantan Barat. Skripsi (Tidak Diterbitkan) Fakultas Ekonomi Dan Bisnis Universitas Tanjungpura.

Wahyuni, H. (2004). The Role Of Government in Economic Growt: Evidence From Asia and Pasific Countries. Journal of Indonesian Economic and Bussines, 19(1), 71 81.

Wibisono, Y. (2005). Sumber - Sumber Pertumbuhan Ekonomi Regional: Studi Empiris Antara Provinsi di Indonesia. Jurnal Ekonomi Dan Pembangunan Indonesia, 5(2), 224-235. 